\title{
Central File Number
}

National Cancer Institute

\section{Source}

National Cancer Institute. Central File Number. NCI Thesaurus. Code C134005.

A seven digit number assigned by the Food and Drug Administration (FDA). 